\title{
備讃瀬戸航路のイノサキノツガイ周辺における流れと地形変化 Flow and Topography Change around Inosakinotsugai in Bisan-seto Fairway
}

\author{
伊福 誠 $^{1} \cdot$ 和田進太郎 ${ }^{2} \cdot$ 中田正人 ${ }^{3}$ \\ M akoto IFUKU, Shintaro WA DA and M asato NAKATA
}

\begin{abstract}
This study presents the results of flow, topography change and time variation of accretion or erosion rates for a symmetric semi diurnal tide around Inosakinotsugai in Bisan-seto fairway. Sediment accumulates at the region which is locally dredged and the volume is approximately $19,775 \mathrm{~m}^{3}$ during 7 years. The numerical analysis was carried out by LES(L arge Eddy Simulation). The flow accelerates and diverges radially during the westward current and converges during the eastward current near the top of slope around Shiogama. These numerical results of flow accord with the measured results by ADP. The volume of sediment which accumulates in the pocket is approximately $4.0 \mathrm{~m}^{3}$ during a semi diurnal tidal cycle and this value is approximately 0.85 times as much as it of measured one.
\end{abstract}

\section{1はじめに}

備讃瀬戸航路のうち北航路と南北連絡航路の交差部に 位置する通称「イノサキノッガイ地区」(図-1中の実線で 囲んだ領域）では，起伏の大きい海底の地形変動（以下, サンドウェーブと記す）が顕著になったため，1981〜 1983年にかけて維持浚渫を実施した。ささらに，2001年か らは確保すべき計画水深より浅くなった同海域の維持浚 渫を5 力年計画で実施した（国土交通省四国地方整備局， 2007).

伊福ら（2002）は，1981～1983年の維持浚渫が完了し た翌年の1985年から定期的に実施されているイノサキノ ツガイ地区周辺の深浅測量結果に基づいた解析を行い, さらに, 中田ら（2005）は，2000年と2001年に打ける西 側塩釜から東側塩釜に至る領域の広域深浅測量結果, 2002 2004年における牛島から三ッ子島間の深浅測量結 果㧍よび潮流観測結果に基づいてイノサキノッガイ地区 を含む西側塩釜から東側塩釜に至る領域の土砂移動につ いて詳細に解析し，イノサキノッガイ地区および南北連 絡航路におけるサンドウェーブの形成および発達, 土砂 の移動状況について調べ, 小笹（1975）が推測した三ッ 子砂嘴からの土砂移動がサンドウェーブ形成の主要因で あるとの考えとは異なる結論を見出した.

すなわち，イノサキノッガイ地区周辺のサンドウェー ブは，保全区域外を含めた三ツ子砂嘴西側（南北連絡航 路部, 図-1中の $x=4,500 \mathrm{~m}, y=2,300 \mathrm{~m}$ 付近）を分岐点と した北側の反時計回りの土砂循環と南側の広範囲に及ぶ時 計回りの土砂循環によって形成・保持されている（図-2）.

\begin{tabular}{|c|c|c|}
\hline 1 フェロー & 工博 & (株)エイト日本技術開発 技術本部 \\
\hline 2 正会員 & 工修 & $\begin{array}{l}\text { (株)エイト日本技術開発 } \\
\text { 国土インフラ事業部 }\end{array}$ \\
\hline 3 正会員 & 博(工) & $\begin{array}{l}\text { (株) ワイエスアイ・ナノテック } \\
\text { 応用技術部 }\end{array}$ \\
\hline
\end{tabular}

伊福・魚下（2010）は，LESを用いた図-1中の牛島と 本島の間に位置する西側塩釜近傍の流れや地形変化の解 析から, 東流時の地形変化が西流時より大きく, 牛島の 南側から回り込む流れによって砂の移動量が多くなるこ とから，この流れが牛島東側のサンドウェーブを形成す る要因ではないかと推測している。 また, 伊福・魚下 （2011）は, 図-1中の与島南側に位置する東側塩釡近傍の 流れや地形変化の解析から, 大潮の西流時, 三ッ子島周 辺に抒いて確認された広域に拡がる浮遊砂雲は0.1 mm程 度の比較的小さな底質粒径と関連していること，また， 塩釜法肩付近での侵食・堆積が馬ノ背状地形の形成要因 になっていることを明らかにしている。 さらに, 和田ら （2012）は, 図-1中の与島南側に位置する東側塩釜近傍の 流れや地形変化の解析から, 東流後の地形変化が西流時 の流れや地形変化（あるいはその逆）に及ぼす影響は小 さいこと, 塩釜法肩付近の砂の移動は東流時が卓越して おり，塩釜周辺のコブ状地形（図-1中のhump）や馬ノ背 状地形（図-1中のhorseback）の形成には東流時の流れが 梁く関わっていることを明らかにしている。しかしなが ら, これらの研究は対象とした半日周潮のうち, 東流抒 よび西流最強時の前後1時間の計4時間を解析対象とした ものであり，一周期を対象とした取り扱いはなされてい ない,さらに, 底質は均一砂で構成され, 混合砂として の取り扱いもなされていない.

国土交通省（2005）は，2001年からの維持浚渫を実施 する中で航路の埋没を軽減するとともに浚渫間隔を遅延 化する目的で土砂の堆積が顕著な領域にポケット浚渫を 計画し, 2003年から浚渫を実施して2005年に完了した.

こうしたことから, 本研究では, 2001年以降の深浅測 量結果に基づいてポケット淩渫領域における海底地形変 動について調べ, ポケット浚渫が浚渫間隔の遅延化に及 ぼす効果について検討するとともに, 深浅測量結果に基 


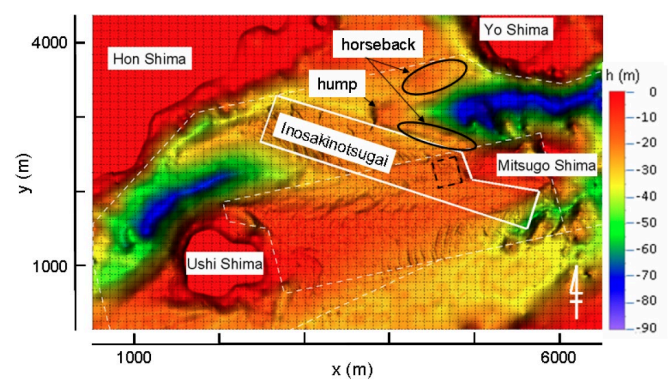

図-1 イノサキノツガイ地区周辺の海底地形

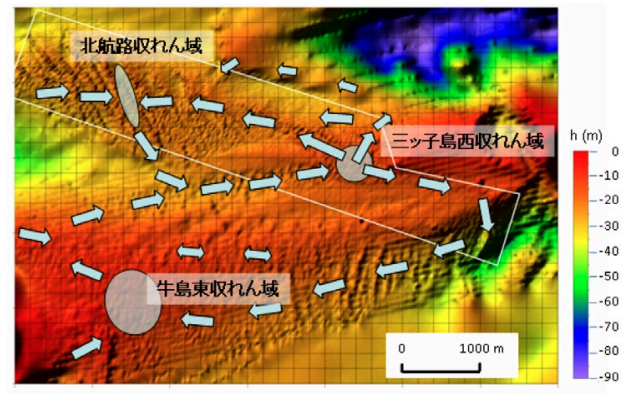

図-2 推測した土砂の移動経路(中田ら, 2005)

づいた海底地形モデルを作成し，均一砂および混合砂を 対象として，3次元LESを用いて計算し，海底地形の時間 的変化や一潮汐間の漂砂量, 底質を構成する粒径の違い が地形変化に及ぼす影響について調べ，航路の維持・管 理に対する基礎的資料を得ようとしたものである.

\section{2深浅測量結果の解析}

\section{（1）2005年から 2012年にかけての地形変化}

図-3はポケット浚渫が終了した2005年と2012年の地形 変化を比較したものである。実線部分はイノサキノッガ イ地区, 破線部分がポケット浚渫の領域（東西300 m, 南北350 m）である。なお，測量はマルチビームで行わ れた. 水深が比較的浅い牛島から三ッ子島にかけては地 形の変動は比較的小さく, イノサキノツガイ地区の北西 端付近で比較的規模の大きいサンドウェーブが形成され ている領域での地形変化が大きい. また，ポケット浚渫

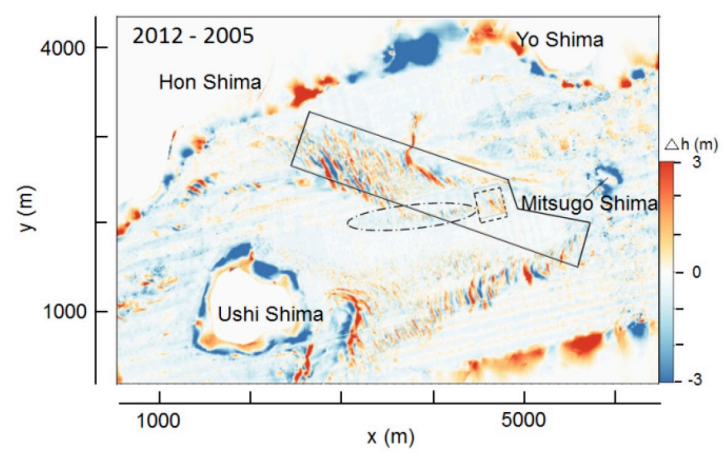

図-3 2012年と2005年の地形差分
領域についても, 最大で2 $\mathrm{m}$ 程度の土砂の堆積が確認さ れる. これは，西側塩釜から $x=2,000 \mathrm{~m}, y=3,000 \sim 4,200$ $\mathrm{m}$ 付近（一点鎖線で示した楕円領域）に形成される峡谷 に沿う東側への土砂移動に起因すると考える.

\section{(2) ポケット浚渫領域の断面変化}

2002年以前の測量は4素子音響測深器で行われた。

図-4は図-1中のポケット浚渫領域における $\mathrm{x}=4,650 \mathrm{~m}$ 断 面の2001，2002および2005年における深浅測量結果であ る. 2005年はポケット浚渫が完了した年であり, 図中の 破線間がポケット浚渫の領域である。

ポケット浚渫が完了した2005年と比較すると，2001年 には最大で $6 \mathrm{~m}$ 程度の堆積が確認される，イノサキノッ ガイ地区における浚渫が進行した2002年においても, 水 深19 mの維持浚渫が完了したy $=2,200 \mathrm{~m}$ 地点より北側を 除けばほぼ同程度の堆積が生じている。

図-5は, 図-1中のx=4,650 mにおけるy $=1,600 〜 2,600 \mathrm{~m}$ 断面の2005年と2012年における水深を示したもので, 2 本の破線間がポケット浚渫の範囲である. ポケット浚渫 範囲のy $=2,260 \mathrm{~m}$ 付近では侵食されている。侵食された 土砂は北側航路へ落ち込み堆積している。このことは, 北側法肩の水深が南側法肩のそれより深く，壁としての 土砂流出防止機能が南側より低いことに起因する.

2001年以前の深浅測量結果に基づいたポケット浚渫領 域における詳細な解析は行っていないので, どの程度の 時間を経て土砂が堆積したかは明らかではないものの, 図-4中の2001年と2002年および図-5中の2012年にはy $=2,100 \mathrm{~m}$ 付近において堆積量が最大となっていることを 考えれば，ポケット浚渫を行った領域には今後も土砂の 堆積が続くことが予測される。このことから, 深浅測量

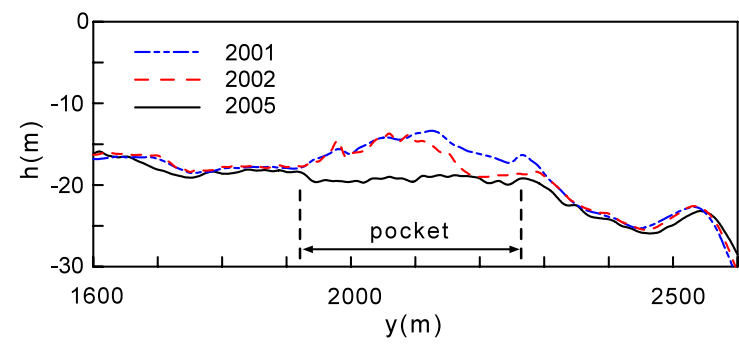

図-4 2001, 2002, 2005年の水深 (図-1中の $x=4,650$ m)

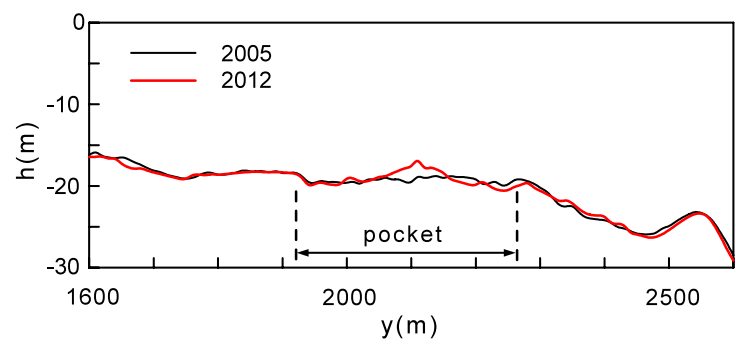

図-5 ポケット周辺の水深変化 (図-1中の $\mathrm{x}=4,650 \mathrm{~m}$ ) 
結果の解析を通して計画されたポケット浚渫は航路埋没 を軽減する有効な施工法であると考える．

\section{3. 数值解析}

\section{（1）基礎方程式}

流れ，掃流層内の濃度，浮遊砂抢よび地形変化の計算 に用いた基礎式や式に含まれるパラメータおよび境界条 件の設定，計算方法については，伊福・魚下（2011）を 参照されたい。 なお，解析には $\sigma$ 座標を用いた。

\section{(2) 解析領域・解析時間帯}

解析領域は, $x$ 方向 $7,000 \mathrm{~m}, \mathrm{y}$ 方向4,350 mである. な お， $x$ およびy 方向の格子間隔は $10 \mathrm{~m}$ であり, 水深方向 は20等分，時間間隔は 0.5 sとした，図-6に示すように流 れは6周期分を計算し，地形変化の計算は2周期目から6 周期目までとした。

\section{(3) 潮位差, 底質}

周期は12時間，潮位差は2.5 m, 底質は小笹（1975）が 得た粒度分布をもとに, 均一砂の粒径は $0.58 \mathrm{~mm}$, 混合 砂の粒径抒よび底面における占有率は，それぞれ0.35, $0.5,0.7 \mathrm{~mm}$ (平均粒径 : $0.58 \mathrm{~mm}$ ) および $0.25,0.50$, 0.25 とした。 また, 海底の空隙率は 0.4 , 限界摩擦速度の 評価にはEgiazaroff（1965）の式を用いた。 なお，沈降速 度はRubey（1933）の式で算出した。さらに, 海底面変 動の計算には海底勾配の影響を考慮した渡辺ら（1984） の式を用い，式中に含まれる定数は1とした，掃流漂砂 量はM eyer-Peter・M üller（1948）の経験式で算出し, 浮 遊砂濃度および浮遊漂砂量は伊福・魚下（2010）の方法 で求めた。

\section{4. 数値解析結果}

\section{(1) 流れ}

図-7は，東流最強時における海面下 $1 \mathrm{~m}$ の流速べクトル を示したものである。なお, 図中の実線は初期等深線, 赤破線の部分はポケット浚渫領域である.

東側塩釜の法肩付近では南北より塩釜中央に向かう流 れが生じ，流速は0.7 0.8 m/s程度である。 また，三ッ子 島周辺に抒いては三ッ子島を回り込む流れが生じてお り, 東側は遮蔽域となるため, 流速は $0.1 \mathrm{~m} / \mathrm{s}$ 程度であり, 逆流域の形成もみられる。ささらに，与島の南側および牛

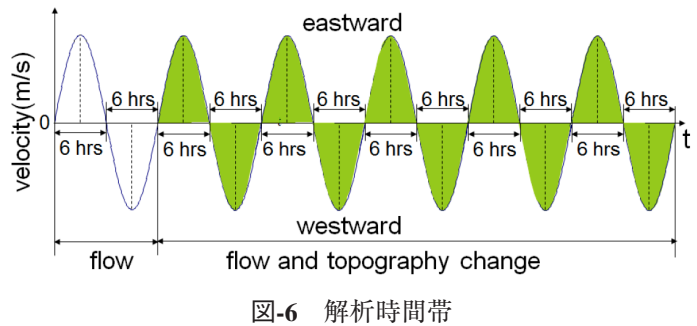

島付近においては，島を回り込むような流れが生じてい る.なお，西側塩釡の中央付近㧍よび法面付近における 流速は0.7 m/s程度である。また, $x=2,500 〜 3,500 \mathrm{~m}$, $\mathrm{y}=2,500 \sim 3,200 \mathrm{~m}$ の範囲には比高が2〜4 mで波長が100 $200 \mathrm{~m}$ の比較的規模の大きいサンドウェーブが形成され ており, 栈粗度の役割を担うため流速は小さくなったと 思われる。

図-8は，国土交通省が2007年にADPを用いて行った観 測で得た東流時の表層に扔ける流速べクトルである。東 側塩釜の法肩付近では塩釡中央へ入り込む流れが生じ， 流速は0.6 0.7 m/s程度であり, 計算結果と比較すると 0.1 $\mathrm{m} / \mathrm{s}$ 程度小さい。 また，東側塩釡の中央付近での流速は $0.8 \mathrm{~m} / \mathrm{s}$ 程度であり，計算結果とほぼ同一である。ささらに， 三ッ子島の東側は遮蔽域により流速は小さく, 与島の南 側および牛島付近においては，島を回り込むような流れ が生じている。 なお，西側塩釡の中央付近での流速は $0.8 \mathrm{~m} / \mathrm{s}$ 程度であり, 計算結果より $0.2 \mathrm{~m} / \mathrm{s}$ 程度大きい。ま た, 西側塩釜の法面付近での流速は $0.9 \mathrm{~m} / \mathrm{s}$ 程度であり, 計算結果より $0.2 \mathrm{~m} / \mathrm{s}$ 程度大きい. なお, 牛島の東側付近 に打いては逆流域が生じているのに対して, 計算結果で は生じていない，さらに，与島から塩釜に向けて舌状に 伸びている比較的浅い領域では流速の増大が確認される.

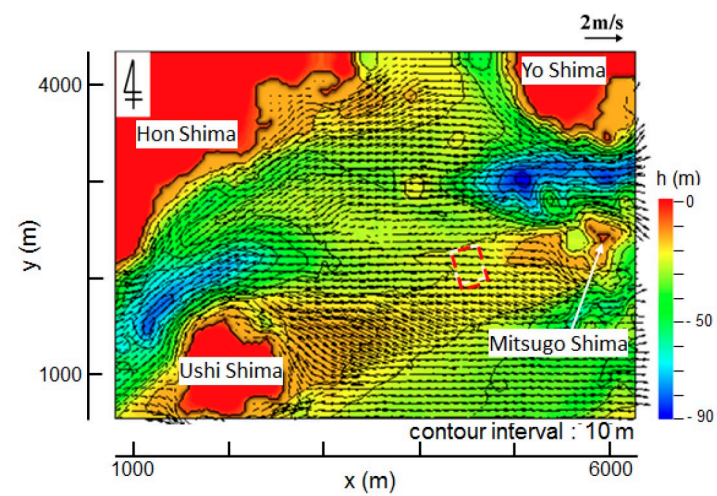

図-7 東流最強時の流速ベクトル (海面下 $1 \mathrm{~m}$ )

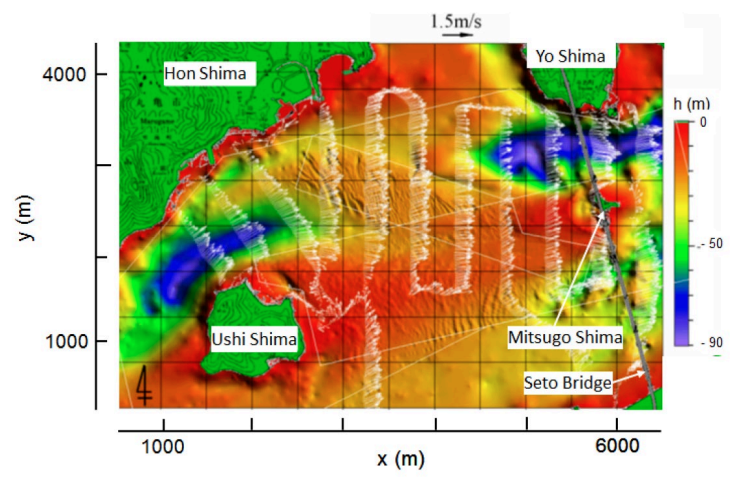

図-8 東流時の観測結果 (国土交通省, 2007) 


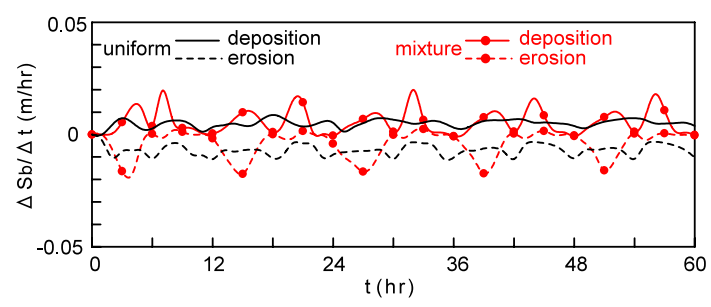

図-9 最大堆積量・最大侵食量の変化率

以上のことから，解析結果は観測結果より流速が小さ いものの，両者はよく似た傾向を示しており，観測結果 の流況をある程度再現できているのではないかと考える.

\section{（2）最大堆積量・最大侵食量}

図-9は, 計算開始後6周期目で堆積量あるいは侵食量が 最大であった地点における単位時間あたりの堆積率・侵 食率である。 なお, 均一砂の場合, 最大堆積量は与島南 側付近の $x=5,680 \mathrm{~m}, \mathrm{y}=3,600 \mathrm{~m}$, 最大侵食量は三ッ子島 の北東付近の $\mathrm{x}=5,640 \mathrm{~m}, \mathrm{y}=2,510 \mathrm{~m}$ で生じている. 一方, 混合砂の場合, 最大堆積量は牛島の南西付近の $x=1,440$ $\mathrm{m}, \mathrm{y}=810 \mathrm{~m}$, 最大侵食量は三ッ子島の北東付近の $\mathrm{x}$ $=5,780 \mathrm{~m}, \mathrm{y}=2,590 \mathrm{~m}$ で生じている.

均一砂の場合，堆積率および侵食率ともに，1時間あ たりの変化量は約 $0.01 \mathrm{~m}$ 以下であり, 12時間以降は大き な変動はないようである。一方, 混合砂の場合, 堆積率 は東流最強時より1時間程度遅れた16，28，40，52時頃と西 流最強時より1時間程度早い20，32，44，56時頃に大きく， とくに, 西流時の堆積率は東流時のそれの1.5倍程度であ る.また, 侵食率は東流最強時付近で約 $0.02 \mathrm{~m} / \mathrm{hr}$ である がその他の時間ではきわめて小さい.

\section{(3) ポケット浚渫領域の土砂量変化}

図-10および11，2005年に終了したポケット浚渫領域 （以下，領域と記す）の浚渫前後における東西および南 北方向の全漂砂量の経時変化を示したものである.また, （a）および（b）は，それぞれ東西および南北方向の結 果である（以下，領域の東西南北の辺をそれぞれE-line， W-line, S-line, N-lineと記す）。なお，浚渫前および浚渫後 の全漂砂量は, それぞれ最大值の $8.25 \times 10^{-4} \mathrm{~m}^{2} / \mathrm{s}$ および 8.24 $\times 10^{-4} \mathrm{~m}^{2} / \mathrm{s}$ で無次元化している.

図-10（a）をみると，東流時にW-lineから領域へ流入 する全漂砂量が多く, E-lineから領域外へ流出する全漂 砂量の最大值は前者の約 $1 / 2$ である. 一方, 西流時には, E-lineから領域へ流入する全漂砂量の最大值はW-lineから 領域外へ流出するそれの約1.4倍である.

図-10（b）をみると，S-lineから領域へ流入する全漂砂 量の最大值はW-lineから領域内へ流入するそれの40\%程 度である。なお， N-lineにおいては一潮汐を通して僅か ではあるが領域から北航路側へ流出する量がある。さら に, S-lineにおいては, 東流時に領域外へ流出し, 西流時

に領域内へ流入しているが，一潮汐平均すると領域内へ 流入する.

図-11（a）をみると，図-10（a）と同じく東流時に W-lineから領域へ流入する全漂砂量が多く, E-lineから流 出する全漂砂量の最大值は前者の35\%程度であり, 図-10 （a）と比較すると，その割合は減少している。一方，西 流時には, E-lineから領域へ流入する全漂砂量の最大值 は, W-lineから領域外へ流出する全漂砂量の約2倍である.

図-11（b）をみると，領域内へ流入および領域外へ流 出する全漂砂量の経時変化は図-10 (b) と似た傾向を示 す。詳細にみると，西流時にS-lineから領域内へ流入する 時間が僅かに短いようである.

図-12は, 一潮汐間に領域に流入および領域から流出す る全漂砂量を示したものであり，(a) および（b）は， それぞれポケット浚渫前および浚渫後の結果である.

（a）をみると，W-lineにおいて西側から流入する全漂 砂量とE-lineにおいて東側から流入する全漂砂量が多い. また, W-lineから領域へ流入する全漂砂量の10\%程度が N-lineから北航路へ流出している. 流出入量の総和をみ ると，一潮汐間に領域内へ約 $5.1 \mathrm{~m}^{3}$ 流入する.

（b）をみると，領域へ流入および領域から流出する全 漂砂量は, N-lineにおいて領域内へ流入する全漂砂量を 除けば, いずれのlineにおいても減少している.このこ

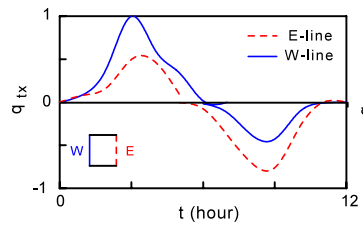

(a) E-line および W-line

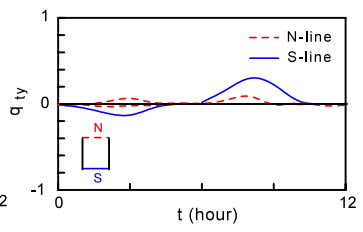

(b) N-line および S-line

図-10 ポケット浚渫前における全漂砂量の経時変化

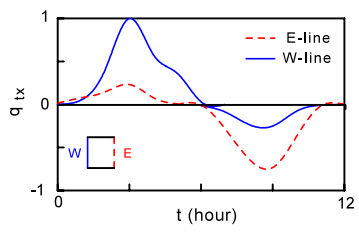

(a) E-line および W-line

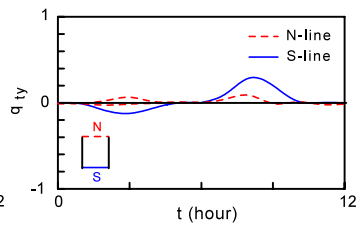

(b) N-line および S-line
図-11 ポケット浚渫後における全漂砂量の経時変化

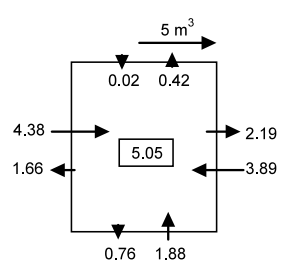

(a) 浚渫前

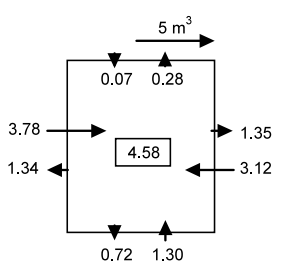

(b) 浚渫後
図-12 ポケット浚渫前後における一潮汐平均の全漂砂量 
とは, 浚渫により領域内の水深が2 $\mathrm{m}$ 深くなり, 流速が 減少したことに伴い砂の移動量が少なくなったためであ ると考える。流出入量の総和をみると，一潮汐間に領域 内へ約 $4.6 \mathrm{~m}^{3}$ の流入があり，これは浚渫前の約 $90 \%$ あるる. 2001から2012年の深浅測量結果をみると, 領域におい ては，2005年から2012年までの7年間で19,775 mほ ぼ土 砂が堆積している．単純平均すると 1 年間で $2,825 \mathrm{~m}^{3}$ ほど の堆積量である. 半日周潮を対象として考えれば, 1 周 期あたり $4.0 \mathrm{~m}^{3}$ ほどの堆積が生じたことになる。この結 果と図-12 (b) を比較すると, 計算で得た結果は観測結 果の約1.15である。15\%程度の差はあるが，計算結果は ほぼ観測結果を再現し得ているのではないかと考える.

しかしながら, 本研究では日潮不等の影響を無視して いるので, それを考慮した場合, 観測結果と解析結果と の差が増大する可能性があることは否定できない.

以上, 深浅測量結果の解析および数值解析結果から判 断すると, 中田らが推測したイノサキノッガイ地区周辺 における土砂移動はほぼ妥当であると考える，今後は日 潮不等を考慮した解析をする必要があると考える.

\section{5. おわりに}

本研究では, 深浅測量結果の解析やLESを用いた3次元 数值解析によって, 備讃瀬戸航路周辺の流れや地形変化, とくにポケット浚渫の効果について検討した.

その結果を要約すると以下の通りである.

（1）2001および2002年におけるポケット浚渫領域では6 $\mathrm{m}$ 程度の堆積が確認される。 また，ポケット浚渫後の 2012年にはポケット内の中央付近において $2 \mathrm{~m}$ 程度の堆 積が生じていることを考え合わせれば，ポケット浚渫領 域には今後も土砂の堆積が続くことが予測される.

(2) 樑浅測量結果をみると, ポケット浚渫領域では徐々 に堆積が進み，2005年から2012年までの7年間で19,775 $\mathrm{m}^{3}$ ほど堆積している．単純平均すると 1 年間で2,825 $\mathrm{m}^{3}$ の 堆積量, 半日周潮を対象とすると, 1 周期あたり $4.0 \mathrm{~m}^{3}$ ほ どの堆積が生じたことになる。

（3）東流最強時における解析領域の流況は, 南北より東 側塩釡中央に向かって収斂する流れが生じ，三ッ子島を 廻り込む流れも確認できる。解析結果は観測結果より流 速が僅かに小さく, また, 東流時の観測結果において牛 島の東側付近で生じている逆流域は再現できていないも のの, 観測で得た流況をほぼ再現し得ている.
（4）一潮汐間のポケット浚渫部の流出入量をみると, $\mathrm{N}$-lineで流入量より流出量が多い。これは北側法肩の水 深が南側法肩のそれより深く, 壁としての土砂流出防止 機能が南側より低いことに起因する。計算による領域内 への流出入量の総和は, 約 $4.6 \mathrm{~m}^{3}$ の流入で観測結果の約 1.15倍であり，解析結果は観測結果とほほ一致する。

（5）浚渫前後に打ける全漂砂量の経時変化, 一潮汐平均 の全漂砂量および解析領域の海底地形変動から判断する と, 中田らが推測したイノサキノッガイ地区周辺に扔け る土砂移動はほぼ妥当であり, ポケット浚渫は有効な施 工法である。

謝辞：貴重な深浅測量結果は国土交通省四国地方整備局 から提供して頂いた。ここに記して，深甚なる謝意を表 する。

\section{参 考 文 献}

伊福 誠・ 小林泰之 - 坂田健治 - 西本光宏 - 中田正人 (2002)： 深浅測量結果に基づく備讃瀬戸航路の地形変化, 海岸工 学論文集, 第49巻 (1), pp.556-560.

伊福 誠・魚下一平 (2010)：牛島北側の塩釜周辺に抄ける流 れと地形変化, 土木学会論文集B2, Vol.66, N o.1, pp.691695.

伊福 誠・魚下一平 (2011)：大潮時の塩釜周辺に打ける流れ . 地形変化と浮遊砂雲, 土木学会論文集B 2, V o l.67, N o.1, pp.I $581-1585$.

小笹博昭（1975）：備讃瀬戸に扩ける海底砂, サンドウェーブ の調查，港湾技術研究所報告, 第14巻, 第2号, $45 \mathrm{p}$.

国土交通省四国地方整備局高松港湾・空港整備事務所 （2005）：備讃瀬戸航路サンドウェーブ調查報告書, pp.216-221.

国土交通省四国地方整備局高松港湾・空港整備事務所 （2007）：備讃瀬戸航路サンドウェーブ調查報告書，84p.

中田正人 · 伊福 誠·三野真治 (2005)：借讃瀬戸航路に扩け る深浅測量と潮流観測に基づいたサンドウェーブの解析, 海岸工学論文集，第52巻，pp.606-610.

渡辺 晃・ 丸山康樹 - 清水隆夫 - 榊山 勉 (1984）：構造物設 置に伴う三次元海浜変形の数值予測モデル，第31回海岸 工学講演会論文集, pp.406-410。

和田進太郎 - 小貫修平 - 門田純一 - 伊福 誠 (2012)：東流 西流時に打ける与島の南側塩釜周辺に扔ける流れと地形 変化，土木学会論文集B2, Vol.68, No.2, pp.I_616-I_620.

Egiazaroff, I.V.(1965) : Calculation of nonuniform sediment concentrations, J.Hydraulic Div, A SCE, Vol.91, N O.HY 4, pp.225-247.

M eyer-Peter, E. and R.M üller(1948) : Formulas for bed-load transport, Proc. 2nd IA HR Congr., pp.39-64.

Rubey, W.W.(1933) : Settling velocities of gravel, sand and silt particles, A merican J ournal of Science Ser.5, Vol.25, N o.148, pp.325-338. 